\title{
The Dynamics of Aggressive Behavior in Childhood and Adolescence and the Role of School: Implication for Practice
}

\author{
Elias Kourkoutas', Pilios-Dimitris Stavrou ${ }^{2,3^{*}}$ \\ ${ }^{1}$ Department of Primary Education, University of Crete, Rethymno, Greece \\ ${ }^{2}$ Department of Psychology, University of Athens, Athens, Greece \\ ${ }^{3}$ Laboratory of Clinical Psychology, Psychopathology and Psychoanalysis (PCPP), Paris Descartes University-Sorbonne, \\ Paris, France \\ Email: hkourk@edc.uoc.gr, *stavroupd@gmail.com
}

How to cite this paper: Kourkoutas, E., \& Stavrou, P.-D. (2018). The Dynamics of Aggressive Behavior in Childhood and Adolescence and the Role of School: Implication for Practice. Psychology, 9, 2116-2134. https://doi.org/10.4236/psych.2018.98121

Received: July 2, 2018

Accepted: August 12, 2018

Published: August 15, 2018

Copyright (c) 2018 by authors and Scientific Research Publishing Inc. This work is licensed under the Creative Commons Attribution International License (CC BY 4.0).

http://creativecommons.org/licenses/by/4.0/

\begin{abstract}
Problematic/aggressive behavior in children and adolescents stems from complex interactions between developing self-patterns and contextual influences, but also holds a symbolic and subconscious meaning related to each child's and adolescent's inner reality and experiences. This review presents the theoretical background, the scientific rationale and the practical implications of an innovative multidimensional model for addressing problematic/ aggressive behavior of children and adolescents at school. This model, based on extensive clinical work with children and adolescents and research evidence from its implementation in Greek schools, incorporates the psychodynamic, interpersonal, social, cognitive and multi-systemic perspective, offering a holistic approach intervention. On a practical level, this model translates to the application of a variety of techniques by a multidisciplinary team and involves individual support, psychotherapy, counseling and guidance of children themselves, their families and their teachers. This model moves away from the traditional psychiatric view of children's problematic behaviour, promoting a comprehensive school-based mental health framework that appears to be promising in addressing children's and adolescents' behavior problems and emotional difficulties.
\end{abstract}

\section{Keywords}

Problematic/Aggressive Behavior, Multidimensional Model, Holistic Approach, School-Based Mental Health Framework 


\section{Introduction}

The dynamics of child development unavoidably include behaviors that have an "aggressive" character. Aggression is defined as a range of behaviors that result in harm to one's self, others or the general environment (Kauffman \& Landrum, 2013). This range of behaviors can take several forms, such as physical, psychological, verbal, emotional, and sexual, and all forms can gradually evolve in more serious expressions, under specific circumstances and under the impact of specific individual or contextual factors (Dishion \& Patterson, 2006; Frick, 2006; Mash \& Wolfe, 2013). Infants and young children often behave aggressively, as they lack the proper psychosocial skills, self-control mechanisms and emotional-cognitive strategies to communicate their desires and needs (Renouf, Brendgen, Séguin, Vitaro, Boivin, \& Perusse 2010; Tremblay, 2003, 2010). However, as children grow up, their affective-cognitive schemas and internal working models that shape behavior are increasingly organized and structured in accordance with external expectancies, rules, and recommendations or positive emotional experiences. The conversion of aggression into acceptable behavior is a key factor for successful socialization in childhood.

In our paper, we adopt a more general and widen view of aggressive behavior in childhood that includes various forms of overt, covert, physical, or verbal, and relational hostile reactions and behavioral trends from mild dysfunctional to destructive and highly intentional. Aggressive behavior might be instrumental or reactive, may include an early or adolescent onset antisocial character and may be linked to a variety of emotional states, purposes, or intentions (such anger, rage, feeling of revenge, or sadistic and destructive trends) (Dishion, 2014; Frick \& Kimonis, 2008). Disruptive behavior (such as emotional tantrums) may also include an aggressive note, character, or purpose that is not initially apparent. Therefore, we prefer to use the term aggressive in a more generalized way in order to focus more to the behavior's impact or its emotional, interpersonal and developmental character, as in childhood mental health structures are still in move and growth and have not usually been crystallized and stabilized, as in adult life (Kourkoutas, 2012). Moreover, contemporary research on taxonomic and epistemological issues highlights the need to consider problematic or aggressive behavior in a dimensional and highly contextualizing perspective ( $\mathrm{Cog}$ hill \& Sonuga-Barke, 2012; Dirks, De Los Reyes, Briggs-Gowan, Cella, \& Wakschlag, 2012). Children live and grow in relational and emotional systems, meaning that it is a methodological dearth or mistake to consider, asses, diagnose or treat them out of this context (Dishion, 2014; Kourkoutas, 2012; Sameroff, 2009). A psychodynamic view is also enriched in that sense that allow for a deeper insight into the often confusing or troubling inner/emotional world, "under construction" of children (Sroufe, Egeland, Carlson, \& Collins, 2005).

\section{Reviewed Approaches}

The socialization process implies the development of a series of internal and 
external mechanisms and skills that promote healthy adjustment and resolution of intrapersonal and interpersonal challenges (Bierman \& Sasser, 2014; Renouf, et al., 2010; Tremblay, 2003, 2010). Prevailing forms of dysfunctional or harmful-to-others aggressive and troubling behavior may indicate failed socialization processes or dysfunctional internal working models and hostile feelings. Moreover, it may indicate inadequate skills and coping mechanisms to deal with these internal or external challenges, distresses, or negative emotions related to traumatic experiences for a series of reasons (Sroufe et al., 2005). From this perspective, social adjustment is viewed as a dynamic process implying an endless and multidimensional interaction between a series of internal resources and features, and external factors that respectively shape children's capacities and skills. The transactional models have proved to be a very useful theoretical framework to illuminate these complex psychosocial phenomena (Fraser, 2004; Sameroff, 2009, 2014).

This concept inevitably emphasizes a broader approach that perceives psychosocial environment as a significant factor contributing to psychopathology; aggressive behavior is considered a result of complex interactions between the developing self-patterns of adjustment and an external context that is unable to provide the child with the necessary framework for developing adequate skills (systemic view) (Boxer \& Frick, 2008; Compton et al., 2003; Dishion, 2014; Dodge, 2006; Dodge \& Pettit, 2003; Fraser, Kirby, \& Smokowski, 2004; Kauffman \& Landrum, 2013; Liu et al., 2013; Sameroff, 2009, 2014; Sroufe et al., 2005; Williams et al., 2004; Wyman, 2003). In other words, aggressive or disordered behavior is regarded as part of a wide range of psychological disturbances that result from continuous and accumulated problematic interactions between external parameters and insufficient internal mechanisms or deficit skills (Carr, 2006; Dishion, 2014; Gendreau \& Archer, 2005; Williams et al., 2004). This concept surpasses the classical medical one-dimensional approach, providing a holistic view of the child's disordered behavior by emphasizing the role of the environment and the contextual (risk and protective) factors in childhood "pathology" (Carr, 2006, 2009; Bierman \& Sasser, 2014; Dishion, 2007; Fraser \& Allen-Meares, 2004; Fraser et al., 2004; Kourkoutas, 2012; Kourkoutas \& Wolhuter, 2013; Sameroff, 2009; Timimi, 2002).

Apart from the environmental factors, which play a crucial part in a child's psychopathology, research indicates that unconscious conflicts or intense negative feelings predict aggressive behavior in children; problematic behavior often has a symbolic and communicative character in the sense of a conscious or unconscious transmission/expression of something that comes from the psyche and the relational world of the child, such as negative or conflicting emotions, thoughts, distressing feelings, repressed needs, traumatic experiences (Brady, 2005; Greenwald, 2004; Timimi, 2002; Timimi \& Radcliffe, 2005). Thus, a child's problematic behavior may be an indicator for a problematic emotional functioning or relationship that is unable to be expressed in other ways (Campbell, 2002; Sroufe et al., 2000), not merely a reflection of inner psychophysiological 
processes. Thus, it should be examined in relation to the particular role that it plays and the meaning it bears in the child's psychic "economy" and functioning within the family and interrelationships. Hyperactivity, for example, is now seen by many researchers as not only an expression of neuropsychological dysfunction (i.e. dysfunction of the executive function), but also as an expression of the child's uncontained anguish and an inability to master the psychological stress related to interpersonal exchanges (Brady, 2005; Timimi, 2002).

Another important emotional element, often invisible, that has been linked to disruptive acting outs and aggressive behavior is anger (Scriva, Heriot, \& Kourkoutas, 2015; Tremblay, 2003). According to Putzu-Williams (2015), acting out anger can have different origins, including "unprocessed anxiety and rage" related to infancy or to the family background. In the case of maltreated and neglected children, or children living in dysfunctional families, shame, guilt, and other painful emotions are often "replaced by intense rage that is apparently generated to restore the vulnerable sense of self" (Fonagy, 2004: p. 40). Many aggressive children are characterized by "pseudo-independence" and "rigidity" or an inflated sense of self concealing a feeling of vulnerable self and an inability to deal with emotions. Such children are unable to bond with others in affective ways, as they haven't learned to rely on positive relationships with caring others and, thus, have not sufficiently internalized positive affective experiences and self-recognition (Rohner, 2016). Unprocessed bereavement and loss may lead to a form of agitated depression dominated by angry outbursts (Putzu-Williams, 2015).

It is worth noting that in extreme forms of aggressive disruptive behaviors, such as antisocial acts, research showed that these behaviors are hotly emotionally charged acts, stemming from a trauma related psychopathology background (Steiner et al., 2011).

Overall, the family context and the relationship with the parents have a great impact on children's interpersonal skills and development of psychopathology (Neece, Green, \& Baker, 2012; Stavrou, 2018b). For example, both child temperament and quality of the parent-child relationship shape social-competence and self-regulation skills. Children who are socially competent are likely to demonstrate low reactivity to stress and have high self-control of their attention and behavior. However, the psychosocial context in which a child develops seems to play a central role in the maturation of interpersonal skills and self-emotions regulation systems (Ares, Kuhns, Dogra, \& Karnik, 2015; Dishion, 2007; Sroufe et al., 2005). Studies on gene-environment interplay provided evidence that maternal disengagement moderates genetic influences on the development of externalizing problems (Boutwell, Beaver, Barnes \& Vaske, 2012). Children living in supportive and encouraging family and school contexts are more likely to develop social-competencies and self-regulation skills. In contrast, when children live in hostile and dysfunctional families, where parents are of low self-competencies and use inappropriate parenting strategies, they are more likely to develop social, emotional, and behavioral difficulties or conduct problems (Davis \& 
Sturge-Apple, 2014; Serbin \& Krap, 2004; Snyder, 2016; Thornberry, Freman-Galant, Lizotte, Krohn, \& Smith, 2003; Zoccolillo et al., 2005).

Overall, children with mild emotional or social interpersonal and behavioral difficulties may face increased risks and difficulties, when they enter school. Early academic difficulties, poor social skills, and poor problem-solving abilities are associated with behavior problems.

\section{Systemic Developmental Thinking and Behavioral Problems}

It is increasingly recognized that children rarely experience isolated mental health problems and that most behavioral difficulties occur in combination with other psychosocial difficulties or disorders (Bierman \& Sasser, 2014; Dishion, 2007; Frick et al., 2013). Moreover, multiple risk factors are implicated in the development of behavior problems accompanying additional psychosocial or academic difficulties, thus requiring numerous strategies of assessment and intervention (Ares et al., 2015; Dishion, 2007; Forness, 2003).

As it has already been outlined, the problematic reactions of children and adolescents are no longer regarded as a one-dimensional problem, but as the result of dynamic interactions among many complex factors (Dishion, 2014; Kourkoutas, 2012). These considerations promote a multifactorial model of behavior problems and disorders in childhood, without necessarily underestimating biological predispositions or temperament issues (Dishion \& Patterson, 2006; Frick \& Kimonis, 2008). At a theoretical level, most of these approaches include the systemic and social interactive/transactional thinking of behavioral analysis (Sameroff, 2009). They are also based on data from longitudinal studies, which during the last few decades have refined the methodological measures and statistical methods of analysis used in the field.

The developmental and systemic dimension in contemporary psychopathology and special education includes the following characteristics:

- Emphasis on capturing developmental changes;

- Emphasis on examining contexts (macro-, meso-, and microsystems);

- Emphasis on continuities/discontinuities of normal and pathological processes;

- Emphasis on historical aspects of children's functioning: pathways and trajectories of change (person + disorder);

- Emphasis on capturing adaptive and maladaptive functions and patterns;

- Emphasis on social interactional processes and social learning;

- Emphasis on synthesis across domains;

- Building interventions on multisource and multifaceted assessments of children's functioning.

On the other hand, the extreme "medicalization" of children's and families' difficulties/deficits during the past twenty years has brought significant changes in the way children's behavior problems have been described, diagnosed, and treated; in a way, the emphasis on symptoms reduction by all means has considerably concealed the emotional dynamic and developmental nature of behavioral 
problems, as it separates the symptom from children's individual functioning and psychic dynamic, their family and social-school history, as well as their coping strategies (Dishion \& Stormshak, 2006; Kourkoutas, 2012).

\section{Targeted Psychotherapeutic and Psychosocial Interventions}

Four categories of interventions have been developed based on the treatment of children with antisocial tendencies and behavioral problems for which there are adequate research data: 1) behavioral parent training, 2) child-focused problemsolving skills training, 3) functional family therapy, 4) multisystemic therapy for antisocial and delinquent adolescents, and 5) holistic school based interventions which include innovative group or individual clinical or psycho-educational practices/techniques (such as art-based/art-therapy, etc.) along with family and teachers counseling or therapy with an eclectic character (Adelman \& Taylor, 2013; Afuape, 2015; Bierman \& Sasser, 2014; Burke, Loeber \& Birmaher, 2002; Carr, 2006, 2009, 2014; Cefai \& Cavioni, 2015; Dishion, 2014; Kazdin, 2000; Kourkoutas, 2012; Maggin, Wehby, Farmer, \& Brooks, 2016; Weisz, 2004; Winship \& MacDonald, 2018).

Although there are several problems regarding the outcomes of such interventions, such as the limited evidence on improvement of children's actual psychosocial and academic functioning (Roth \& Fonagy, 2005), the lack of lasting, long-term results (Carr, 2009; Kazdin \& Nock, 2003; Roth \& Fonagy, 2005), the lack of ecological validity (Kazdin, 2000; Kazdin \& Nock, 2003; Kourkoutas, 2012) and the uncertainty regarding the mechanisms involved in the changes in children's behavior (Kazdin, 2000; Kazdin \& Nock, 2003; Wampold \& Imel, 2015), holistic approaches such as multimodal models and multisystemic therapy seem to be very effective, even for children and adolescents with severe behavior problems and antisocial tendencies, because they apply to all levels (individual, family, school), using a variety of techniques (Kourkoutas \& Raul Xavier, 2010). The principles and directions of multisystemic holistic interventions are focused on the assessment and understanding of the links between environmental relationships and the emergence and persistence of the symptom, as well as the implementation of customized interventions on an individual, family and social-school level, with emphasis on specific goals, positive reinforcement and skills development.

To determine common elements of mental health programs aimed at providing preventive or early intervention services to at-risk children, Browne et al. (2004) synthesized 23 reviews describing the empirical literature on prevention strategies implemented in or involving schools. The authors found the following common elements of effective prevention and early intervention programs (see also Kutash, Duchnowski \& Lynn, 2006): 1) programs aimed at developing protective factors have shown greater positive results than programs aimed at reducing pre-existing negative behaviors, but vary by age, gender, and ethnicity of children; 2) younger children show greater positive results than older children, 
but some programs are effective for older children; 3) programs directed to address a specific problem have greater effect than broad, unfocused interventions; 4) programming that has multiple elements involving family, school, and community are more likely to be successful than efforts aimed at a single domain; 5) strategies were enhanced when based on and informed by sound theoretical foundations; 6) fear-inducing tactics and delivering information in only a didactic format were generally less effective; and 7) long-term strategies are more effective than short-term strategies when they have the continued presence of appropriate adult staff or mentors.

Overall, professionals (school psychologists, social workers, special educators) who target students at risk or with manifested behavioral or psychosocial problems should build strong partnerships with parents, school teachers, and amongst themselves. The work of Allen-Meares and her colleagues (Allen-Meares, Washington, \& Welsh 2000) reported that professionals working in an ecosystemic perspective seek to achieve the expansion of parents, children and professionals' skills, capacities and knowledge, in order to create a supportive interpersonal web that could foster the implementation of innovative interventions. This conclusion is corroborated by the findings and reports of various clinical and research studies regarding the work with "problematic children and adolescents", their parents, and their teachers (Adelman \& Taylor, 2013; Cohen, 2013; Doran, 2012; Kourkoutas \& Giovazolias, 2015; Maggin et al., 2016; Music, 2009; Music \& Hall, 2007; NFER, 2016; Roeser \& Eccles, 2014; Winship \& MacDonald, 2018).

\section{Holistic Psychodynamic Model}

Based on a large number of clinical interventions in Greek schools with children and adolescents and on empirical data on the development and treatment of children's behavioral problems, a holistic model has been proposed for various groups of children with a multitude of problems and difficulties (Kourkoutas \& Raul Xavier, 2010). At a theoretical level, this model incorporates the psychodynamic/interpersonal and social-cognitive perspectives in a wider multisystemic viewpoint (Kourkoutas, 2012; Kourkoutas \& Hart, 2014; Kourkoutas \& Wolhuter, 2013).

Regarding the clinical intervention component, the suggested model includes the application of different techniques applied by a multidisciplinary team and involve individual psychotherapy and counseling, the academic support of the children where it is necessary, counseling and supportive supervision of teachers and, of course, family psychotherapy, training, or counseling and emotional guidance (Kourkoutas \& Hart, 2014; Kourkoutas \& Raul Xavier, 2010). This holistic model is based on theoretical conceptualization and empirical studies regarding school-based psychotherapeutic/psycho-educational interventions and mental health services delivery already proven successful (Adelman \& Taylor, 2009; 2013; Christner, Mennuti, \& Whitaker 2009; Fraser \& Williams, 2004; Heathfield \& Clark, 2004; Koller \& Svoboda, 2002; Nastasi, Moore \& Varjas 
2004; Paternite, 2005; Reddy \& Richardson, 2006; Rhodes, 2007; Sharry, 2004; Smith \& Fox, 2002; Young et al., 2004; Weare, 2000, 2005; Weare \& Gray, 2003; Weist, 2003; Winship \& MacDonald, 2018).

More specifically, the fundamental theoretical assumptions guiding the philosophy of intervention on a clinical or school-based level are drawn upon the psychodynamic model and contemporary developmental psychopathology and school counseling research (Dodge, 2006; Cohen, 2013; Emde \& Robinson, 2000; Fonagy \& Target, 2003; Fonagy et al., 2004; Fonagy et al., 2006; Sroufe, et al. 2000; Sroufe et al., 2005; Sameroff, 2009). These assumptions are:

- In most cases, the child with serious behavioral problems is primarily a child with disabling emotional difficulties/disorders, and with social, interpersonal, and cognitive deficits/distortions, who struggles to cope with adjustment challenges;

- Some children with conduct/aggressive problems are seriously damaged in their self-schemata-internal working models and emotional functioning, thus displaying truly harmful behavior(s) toward others;

- The experiences of the child within the family greatly affect the development of behavioral and relationship competencies. Social and interpersonal skills and self- and other representations are essentially shaped by the quality of primary attachments with caregivers, and if the quality of these attachments is problematic the development of psychosocial skills is hindered;

- At school, there is often a reproduction of the behavioral and relational patterns that were developed in the family (Ford, 2004; McMahon \& Forehand, 2003). Behind the problematic behaviors, there are dysfunctional internalized working models and unmanageable emotional conflicts deriving from the family, and these worsen at school;

- Intervention of specialists is essential at all levels (individual, family, school) and in all domains (learning, cognitive, behavioral, and interpersonal);

- Focus is on resolving emotional conflicts, changing representations of self and others, modifying behaviors and emotional skills through the development of strong bonds with the teacher, psychologist/counselor, and the resolution of acute family problems (buffering contextual risk factors and enhancing self-protective psychosocial skills); the use of various techniques is often necessary.

As previously stated, in the case of children with challenging behaviors, behavior problems are treated, to some extent, through the implementation of behavioral techniques and the establishment of an accepting and stable controlled educational framework-in collaboration with the teacher-setting clear limits and expectations. However, the psycho-educational and psychotherapeutic interventions are also focused on the internal processes of the child, such as their negative feelings (anger and rage), as well as their cognitive schemas and beliefs that may contribute to the intensification of disruptive behaviors. Effective intervention for pupils with behavioral difficulties is a question maintaining internal and external behavior control. Internal control refers to maintaining intel- 
lectual control over one's emotions using language as a behavior regulating mechanism. Students capable of reflecting on their own behavior may profit from interventions aimed at creating insight and afterthought. Students' behavior is regulated both by their cognitive mechanisms and by the influences or actions of the environment.

\section{Implications for Teachers and Parents}

Teachers definitely require specialized support as they strongly emphasize the rising complexity of pupils', emotional and behavioural difficulties and the higher demands placed upon them in terms of effective dealing with a wide range of issues (Kauffman \& Landrum, 2013; Stavrou, 2018a; Stavrou \& Kourkoutas, 2017). In fact, a positive relationship with a supportive teacher, in combination with early specialist intervention reduces the risk of a student entering an endless cycle of mutual rejection with his peers and teachers, academic and social failure, or drop out (Kauffman \& Landrum, 2013; Kourkoutas, 2012; Kourkoutas, Stavrou, \& Loizidou, 2017; Levine, 2007). Overall, these and other emerging issues strongly suggest that there is an urgent need for school-based counselors to increase their efforts in order to ensure appropriate specialised counselling assistance to teachers who need it (Christner, Mennuti \& Whitaker, 2009). Studies have shown that the implementation of flexible in-school psychosocial and counselling programs, together with the stable involvement of parents and teachers, that target the most vulnerable and at-risk students can be very effective and less costly than more complex mental health services within or outside school (Kourkoutas \& Hart, 2014). Teacher involvement and contribution in practices that aim at helping children at risk is an important element of innovative partnership models of care within school context (Levine, 2007). On the whole, school is considered the ideal site to implement counselling programs that target an increasing number of children and families who are struggling with mild or more serious problems. An important component of such programs is the counseling support of and partnership work with teachers. As suggested by the National Association of School Psychologists, school counsellors should be able to work collaboratively with the teaching personnel to create and maintain a continuum of services to support all students' attainment of academic, social, emotional, and behavioral goals (National Association of School Psychologists, 2010).

Working with parents is another critical parameter of any successful intervention. Parents, through their behaviors, contribute to the maintenance of the problem or its resolution. In addition, through their positive attitude, involvement or detachment, they can facilitate or impede, respectively, the course of psychotherapeutic interventions. At the same time, they can facilitate or annul any creative intervention and any initiative taken by the teachers. Actually, most available data show that interventions that address both individual and contextual risks show a range of positive outcomes (Carr, 2006, 2009, 2014; Fraser \& Allen-Meares, 2004). 
Interventions at the family level relate especially to the modification of dysfunctional relationships and distorted self- and child-perceptions. Furthermore, intervening to modify problematic or pathological relational, communication, and emotional patterns between family members may need considerable effort and critical manipulation on the part of therapists. It is reasonable to believe that, an attempt to cause a systematic change in established family dynamics may take a long time to register. Though this is true for a number of families, there are a lot of cases where the appropriate approach on the part of an experienced specialist may facilitate or enhance the inhibited potential and may lead to important modification of family functioning. We have developed a brief therapy program targeted at revealing and altering the emotional "blockages," "obstructions," or impasses and ambivalences of parents, which can be sourced in their own distressing experiences as children or to their personal history in general. Such experiences usually negatively impact their beliefs and conceptions of parental roles, their investment and expectations of their own children, as well as their rearing capacities.

One of the main purposes of our work with many "dysfunctional" parents is to offer them a "therapeutic space for recreating the child in their mind" and get in touch with their real child (Green, 2000). Indeed, a lot of parents carry a sense of shame which reinforces the sense of "bad", "imperfect" parent, an issue that has to be addressed in the parent's therapy (Horne, 2000). Some of them are deeply ashamed when confronted with therapists, and usually unconsciously reject their own responsibility. Actually, when they seek help from professionals, they believe that therapists will work exclusively with the child or will offer only practical tips to them. Therefore, many parents encounter enormous difficulties in admitting their "bad" practices and in working on them. Hence, the counseling-psychotherapeutic work, in its initial phase, should give space to the process of "containment" that allows "primitive/tough" feelings and narratives of harsh parenting to be expressed. Therapists should receive such feelings or narratives with a high sense of empathy without criticizing the parents, placing such dysfunctional practices in the context of parents' own history and personal problems.

\section{Conclusion}

In conclusion, previous research has shown that there is a need to design more effective intervention programs that will address childhood and emotional problems in a school context (Adelman \& Taylor, 2013; Chrsithin et al, 2009; Kourkoutas \& Raul Xavier, 2010; Weist, 2003). Clearly, designing individual intervention models requires a holistic and highly comprehensive approach. Traditional medical based models do not take into consideration the subjective experience, the context that influences any given behaviour and the underlying emotional processes. Furthermore, adopting a one-dimensional medical based model, which only incorporates the symptoms of a condition, results in a fragmented view of a child's problems, and fails to take into consideration emotional or 
interpersonal dynamics, family background, school pathway, quality of psychosocial skills and coping mechanisms.

Thus, integrating socio-cognitive, behavioral, psychodynamic and developmental theories and techniques when designing a treatment or intervention program allows for a broader approach (Goldenthal, 2005). In order for such an intervention to be effective it is crucial to include trained mental health professionals and teachers, who would cooperate on the underlying philosophy and the practical implementation of the intervention (Fox et al., 2003; Maital \& Scher, 2003; Weare, 2005).

Overall, existing research demonstrates that children with behavioral issues and problematic behaviors are not properly supported by the current model of service delivery (Walker et al., 2004). It is commonly accepted that mental health professionals could play a pivotal role in introducing a comprehensive school-based model, which would acknowledge the significance of children's social and emotional functioning, as stable emotional functioning does affect children's positive mental health.

The initiative to design and deliver programs that promote the school's position in addressing students' mental health issues has already been employed in some Western countries (Adelman \& Taylor, 2009; de Jong, 2005). It has been identified that there are significant factors that contribute to an effective intervention program across the schools in Greece which have made such attempts. Firstly, it is of great importance that schools introduce mental health support in the school curriculum, so that they develop strong relationships with the community, cooperate with the parents, and commit to the improvement of the school environment (Anderson, 2005: p. 219). As Stavrou and Kourkoutas (Stavrou \& Kourkoutas, 2017) suggested, a supportive school environment is crucial in promoting children's resilience and psychosocial well-being.

\section{Conflicts of Interest}

The authors declare no conflicts of interest regarding the publication of this paper.

\section{References}

Adelman, H. S., \& Taylor, L. (2009). Ending the Marginalization of Mental Health in Schools. A Comprehensive Approach. In R. W. Christner, \& R. B. Mennuti (Eds.), School Based Mental Health. A Practitioners' Guide to Comparative Practices (pp. 25-54). New York: Routledge.

Adelman, H.S. \& Taylor, L. (2013). Mental Health in Schools: Engaging Learners, Preventing Problems, and Improving Schools. Thousand Oaks, CA: Corwin Press.

Afuape, T. (2015). Creative Resistance and Collaborative Relationships: Working with Inner-City Young People and Families. In T. Afuape, \& I.-B. Krause (Eds.). Urban Child Mental Health Services (pp. 31-50). London: Routledge.

Allen-Meares, P., Washington, R., \& Welsh, B. (2000). Social Work in the Schools (3rd ed.). Needham Heights, MA: Allyn \& Bacon.

Anderson, S. (2005). Key Factors in Supporting Students with High Needs in Mental 
Health: Discussions with the Mind Matters Plus Demonstration Schools. Australian Journal of Guidance \& Counseling, 15, 214-219. https://doi.org/10.1375/ajgc.15.2.214

Ares, K., Kuhns, L., Dogra, N., \& Karnik, N. (2015). Child Mental Health and Risk Behavior. In B. Kirkcaldy (Ed.), Promoting Psychological Wellbeing in Children and Families (pp. 123-134). New York: Palgrave McMillan. https://doi.org/10.1057/9781137479969.0012

Bierman, K., \& Sasser, T. (2014). Conduct Disorders. In M. Lewis, \& K. Rudolph (Eds.), Handbook of Developmental Psychopathology (3rd ed., pp. 467-487). New York: Springer. https://doi.org/10.1007/978-1-4614-9608-3_24

Boutwell, B. B., Beaver, K. M., Barnes, J. C., \& Vaske, J. (2012). The Developmental Origins of Externalizing Behavioral Problems: Parental Disengagement and the Role of Gene-Environment Interplay. Psychiatry Research, 137, 337-344.

https://doi.org/10.1016/j.psychres.2011.12.032

Boxer, P., \& Frick, P. J. (2008). Treating Conduct Problems, Aggression, and Antisocial Behavior in Children and Adolescents: An Integrated View. In R.G. Steele, D. Elkin, \& M. C. Roberts (Eds.), Handbook of Evidence-Based Therapies for Children and Adolescents (pp. 241-260). New York: Springer. https://doi.org/10.1007/978-0-387-73691-4_14

Brady, G. (2005). ADHD: Diagnosis and Identity. In C. Newnes \& N. Radcliffe (Eds.), Making and Breaking Children's Lives (pp. 49-62). Ross-on-Wye: PCCCS Books.

Browne, G., Gafni, A., Roberts, J., Byrne, C., \& Majumdar, B. (2004). Effective/Efficient Mental Health Programs for School-Age Children: A Synthesis of Reviews. Social science \& medicine, 58, 1367-1384. https://doi.org/10.1016/S0277-9536(03)00332-0

Burke, J. D., Loeber, R. \& Birmaher, B. (2002). Oppositional Defiant Disorder and Conduct Disorder: A Review of Past 10 Years, Part II. Journal of the American Academy of Child and Adolescent Psychiatry, 41, 1275-1293.

https://doi.org/10.1097/00004583-200211000-00009

Campbell, S. (2002). Behavior Problems in Preschool Children: Clinical and Developmental Issues. New York: The Guilford Press.

Carr, A. (2006). The Handbook of Child and Adolescent Clinical Psychology: A Contextual Approach. London: Routledge.

Carr, A. (2009). What Works with Children, Adolescents, and Adults?: A Review of Research on the Effectiveness of Psychotherapy. London: Routledge.

Carr, A. (2014). The Evidence-Base for Family Therapy and Systemic Intervention for Child-Focused Problems. Journal of Family Therapy, 36, 107-157. https://doi.org/10.1111/1467-6427.12032

Cefai, C., \& Cavioni, V. (2015). Mental Health Promotion in School: An Integrated, School-Based, Whole School. In B. Kirkcaldy (Ed.), Promoting Psychological Wellbeing in Children and Families (pp. 52-67). New York, NY: Palgrave McMillan. https://doi.org/10.1057/9781137479969.0007

Christner, R. W., Mennuti, R. B., \& Whitaker, J. S. (2009). An Overview of School-Based Mental Health Practice from Systems Service to Crisis Intervention. In R. W. Christner, \& R. B. Mennuti (Eds.), School Based Mental Health. A Practitioners' Guide to Comparative Practices (pp. 3-24). New York, NY: Routledge.

Coghill, D., \& Sonuga-Barke, E. J. S. (2012). Annual Research Review: Categories versus Dimensions in the Classification and Conceptualisation of Child and Adolescent Mental Disorders: Implications of Recent Empirical Study. Journal of Child Psychology and Psychiatry, 53, 469-489. 
Cohen, J. (2013). Promoting Children's Healthy Development and Ability to Learn. In M. O'Loughlin (Ed.), Psychodynamic Perspectives on Working with Children, Families, and Schools (pp. 15-38). Plymouth: Jason Aronson.

Compton, K., Snyder, J., Schrepferman, L., Bank, L., \& Shortt, J. W. (2003). The Contribution of Parents and Siblings to Antisocial and Depressive Behavior in Adolescents: A Double Jeopardy Coercion Model. Development and Psychopathology, 15, 163-182. https://doi.org/10.1017/S0954579403000099

Davis, P., \& Sturge-Apple, M. (2014). Family Context in the Development of Psychopathology. In M. Lewis, \& K. Rudolph (Eds.), Handbook of Developmental Psychopathology (3rd ed., pp. 143-161). New York, NY: Springer.

https://doi.org/10.1007/978-1-4614-9608-3_8

De Jong, T. (2005). Strengthening Mental Health Programs for Secondary School Students with High Support Needs: A Framework for Effective School Case Management. Australian Journal of Guidance \& Counselling, 15, 156-167. https://doi.org/10.1375/ajgc.15.2.156

Dirks, M. A., De Los Reyes, A., Briggs-Gowan, M., Cella, D., \& Wakschlag, L. S. (2012). Annual Research Review: Embracing Not Erasing Contextual Variability in Children's Behavior-Theory and Utility in the Selection and Use of Methods and Informants in Developmental Psychopathology. Journal of Child Psychology and Psychiatry, 53, 558-574. https://doi.org/10.1111/j.1469-7610.2012.02537.x

Dishion, T. J. (2007). An Ecological Approach to Family Intervention in Early Childhood: Embedding Services in WIC. Intervening Early Conference, University of Oregon, 18-19 September 2007. https://slideplayer.com/slide/8757769/

Dishion, T. J. (2014). A Developmental Model of Aggression and Violence: Microsocial and Macrosocial Dynamics within an Ecological Framework. In M. Lewis, \& K. D. Rudolph (Ed.), Handbook of Developmental Psychopathology (pp. 449-465). New York, NY: Springer. https://doi.org/10.1007/978-1-4614-9608-3_23

Dishion, T. J., \& Patterson, G. R. (2006). The Development and Ecology of Antisocial Behavior. In D. Cicchetti, \& D. Cohen (Eds.), Developmental Psychopathology. Risk, Disorder, and Adaptation (Vol. 3, pp. 503-541). New York, NY: Wiley \& Sons.

Dishion, T. J., \& Stormshak, E. A. (2006). Children's Lives: An Ecological, Family-Centered Approach to Mental Health Care. Washington DC: APA.

Dodge, K. A. (2006). Translational Science in Action: Hostile Attributional Style and the Development of Aggressive Behavior Problems. Development and Psychopathology, 18, 791-814. https://doi.org/10.1017/S0954579406060391

Dodge, K. A., \& Pettit, G. S. (2003). A Biopsychosocial Model of the Development of Chronic Conduct Problems in Adolescence. Developmental Psychology, 39, 349-371. https://doi.org/10.1037/0012-1649.39.2.349

Doran, A. (2012). Meeting with Teachers and Other School Staff. In L. French, \& R. Klein (Eds.), Therapeutic Practice in Schools (pp. 124-130). New York, NY: Routledge.

Emde, R. N., \& Robinson, J. (2000). Guiding Principles for a Theory of Early Intervention: A Developmental-Psychoanalytic Perspective. In J. P. Shonkoff, \& S. J. Meisels (Eds.), Handbook of Early Childhood Intervention (2nd ed., pp. 160-178). Cambridge: Cambridge University Press. https://doi.org/10.1017/CBO9780511529320.010

Fonagy, P. (2004). The Interpersonal Interpretive Mechanism: The Confluence of Genetics and Attachment Theory in Development. In Emotional Development in Psychoanalysis, Attachment Theory and Neuroscience (pp. 113-130). Abingdon-on-Thames: Routledge. 
Fonagy, P., Gergely, G., \& Jurist, E. L. (2004). Affect Regulation, Mentalization and the Development of the Self. London: Karnac Books.

Fonagy, P., \& Target, M. (2003). Psychoanalytic Theories: Perspectives from Developmental Psychopathology. London: Whurr.

Fonagy, P., Target, M., \& Gergely, G. (2006). Psychoanalytic Perspectives on Developmental Psychopathology. In D. Cicchetti, \& D. Cohen (Eds.), Developmental Psychopathology. Vol. 1: Theory and Method (pp. 701-749). New York, NY: Wiley \& Sons.

Ford, J. D. (2004). Traumatic Victimization in Childhood and Persistent Problems with Oppositional Defiance. Journal of Aggression, Maltreatment and Trauma, 6, 25-58. https://doi.org/10.1300/J146v06n01_03

Forness, S. R. (2003). Barriers to Evidence-Based Treatment: Developmental Psychopathology and the Interdisciplinary Disconnect in School Mental Health Practice. Journal of School Psychology, 47, 61-67. https://doi.org/10.1016/S0022-4405(02)00144-9

Fox, L., Dunlap, G., Hemmeter, M. L., Joseph, G., \& Strain, P. (2003). The Teaching Pyramid: A Model for Supporting Social Competence and Preventing Challenging Behavior in Young Children. Young Children, 58, 48-52.

Fraser, M. W. (2004). The Ecology of Childhood: A Multisystemic Perspective. In M. W. Fraser (Ed.), Risk and Resilience in Childhood. An Ecological Perspective (pp. 1-12). Washington DC: NAWS Press.

Fraser, M. W., \& Allen-Meares, P. (2004). Intervention with Children and Adolescents: New Hope and Enduring Challenges. In P. Allen Allen-Meares, \& M. W. Fraser (Eds.), Intervention with Children and Adolescents: An Interdisciplinary Perspective (pp. 532-544). Boston: Allyn \& Bacon.

Fraser, M. W., Kirby, L. D., \& Smokowski, P. R. (2004). Risk and Resilience in Childhood. In M. W. Fraser (Ed.), Risk and Resilience in Childhood. An Ecological Perspective (pp. 13-66). Washington DC: NAWS Press.

Fraser, M., \& Williams, S. A. (2004). Aggressive Behavior. In L. Rapp-Paglicci, C. N. Dulmus, \& J. S. Wodarski (Eds.), Handbook of Preventive Interventions for Children and Adolescents (pp. 100-129). Hoboken, NJ: J. Wiley \& Sons.

Frick, P. J. (2006). Developmental Pathways to Conduct Disorder. Child and Adolescent Psychiatric Clinics of North America, 15, 311-331. https://doi.org/10.1016/j.chc.2005.11.003

Frick, P. J., Blair, R., \& Castellanos, F. (2013). Callous-Unemotional Traits and Developmental Pathways to the Disruptive Behavior Disorders. In P. Tolan, \& B. Leventhal (Eds.), Disruptive Behavior Disorders (pp. 69-122). New York, NY: Springer. https://doi.org/10.1007/978-1-4614-7557-6_4

Frick, P. J., \& Kimonis, E. (2008). Externalizing Disorders. In J. Maddux, \& B. Winstead (Eds.), Psychopathology: Contemporary Issues, Theory and Research (pp. 349-374). Mahwah, NJ: Erlbaum.

Gendreau, P. L., \& Archer, J. (2005). Subtypes of Aggression and Humans and Animals. In R. E. Tremblay, W. W. Hartup, \& J. Archer (Eds.), Developmental Origins of Aggression (pp. 178-201). New York, NY: Guilford Press.

Goldenthal, P. (2005). Helping Children and Families. A New Treatment Model Integrating Psychodynamic, Behavioral, and Contextual Approaches. Hoboken, NJ: J. Wiley \& Sons.

Green, V. (2000). Therapeutic Space for Re-Creating the Child in the Mind of the Parent. In J. Tsiantis (Ed.), Work with Parents: Psychoanalytic Psychotherapy with Children and Adolescents (pp. 25-45). London: Karnac Books. 
Greenwald, R. (2004). The Role of Trauma in Conduct Disorder. In R. Greenwald (Ed.), Trauma and Juvenile Delinquency: Theory, Research and Interventions (pp. 5-23). New York, NY: The Haworth Press, Inc.

Heathfield, L. T., \& Clark, E. (2004). Shifting from Categories to Services: Comprehensive School-Based Mental Health for Children with Emotional Disturbance and Social Maladjustment. Psychology in the Schools, 41, 91. https://doi.org/10.1002/pits.20047

Horne, A. (2000). Keeping the Child in Mind: Thought on Work with Parents of Children in Therapy. In J. Tsiantis (Ed.), Work with Parents: Psychoanalytic Psychotherapy with Children and Adolescents (pp. 47-64). London: Karnac Books.

Kauffman, J., \& Landrum, T. (2013). Characteristics of Emotional and Behavioral Disorders of Children and Youth (International Edition). Boston: Pearson/Merrill.

Kazdin, A. E (2000). Psychotherapy for Children and Adolescents: Directions for Research and Practice. New York, NY: Oxford University Press. https://doi.org/10.1093/med:psych/9780195126181.001.0001

Kazdin, A. E., \& Nock, M. K. (2003). Delineating Mechanisms of Change in Child and Adolescent Therapy: Methodological Issues and Research Recommendations. Journal of Child Psychology and Psychiatry, 44, 1116-1129. https://doi.org/10.1111/1469-7610.00195

Koller, J. R., \& Svoboda, S. K. (2002). The Application of a Strengths-Based Mental Health Approach in Schools. Childhood Education: Infancy through Early Adolescence, 78, 291-294. https://doi.org/10.1080/00094056.2002.10522744

Kourkoutas, E. (2012). Behavioral Disorders in Children: Ecosystemic Psychodynamic Interventions within Family and School Context. New York, NY: Nova Science.

Kourkoutas, E., \& Giovazolias, T. (2015). School-Based Work with Teachers: An Integrative Comprehensive Counseling Model. The European Journal of Counselling Psychology, 3, 137-158. https://doi.org/10.5964/ejcop.v3i2.58

Kourkoutas, E., \& Hart, A. (2014). Suggesting a Resilient and Systemic Oriented Psychodynamic Model to Include Students with Behavioural Problems: Theoretical Issues and Practical Challenges. Rivista di Psicologia Clinica, 2, 147-168.

Kourkoutas, E., Stavrou, P.-D., \& Loizidou, N. (2017). Exploring Teachers' Views on Including Children with Special Educational Needs in Greece: Implication for Inclusive Counseling. American Journal of Educational Research, 5, 124-130.

Kourkoutas, E., \& Wolhuter, C. C. (2013). Handling Learner Discipline Problems: A Psycho-Social Whole School Approach. KOERS Journal for Christians Scholarships, 78, 1-8. https://doi.org/10.4102/koers.v78i3.550

Kourkoutas, E., \& Xavier Raul, M. (2010). Counseling Children at Risk in a Resilient Contextual Perspective: A Paradigmatic Shift of School Psychologists' Role in Inclusive Education. Procedia Social \& Behavioral Science, 5, 1210-1219. https://doi.org/10.1016/j.sbspro.2010.07.263

Kutash, K., Duchnowski, A. J., \& Lynn, N. (2006). School-Based Mental Health: An Empirical Guide for Decision-Makers. Tampa, FL: Louis de la Parte Florida Mental Health Institute Publication.

Levine, J. E. (2007). Learning from Behavior: How to Understand and Help "Challenging" Children in School. Westport, CT: Greenwood Publishing Group.

Liu, J., Lewis, G., \& Evans, L. (2013). Understanding Aggressive Behavior across the Life Span. Journal of Psychiatric Mental Health Nursing, 20, 156-168.

https://doi.org/10.1111/j.1365-2850.2012.01902.x 
Maggin, D., Wehby, J., Farmer, T., \& Brooks, D. (2016). Intensive Interventions for Students with Emotional and Behavioral Disorders: Issues, Theory, and Future Directions. Journal of Emotional and Behavioral Disorders, 24, 127-137. https://doi.org/10.1177/1063426616661498

Maital, S., \& Scher, A. (2003). Consulting about Young Children: An Ecosystemic Developmental Perspective. In E. Cole, \& J. A. Siegel (Eds.), Effective Consultation in School Psychology (pp. 336-364). Göttingen: Hogrefe \& Huber.

Mash, E., \& Wolfe, D. (2013). Abnormal Child Psychology (International Edition). Belmont, CA: Wadsworth.

McMahon, R. J., \& Forehand, R. L. (2003). Helping the Noncompliant Child: Family-Based Treatment for Oppositional Behavior (2nd ed.). New York, NY: Guilford Press.

Music, G. (2009). Containing Not Blaming: Therapeutic Work in Schools. Therapy Today, 20, 20-24.

Music, G., \& Hall, B. (2007). Learning Our Lessons: Some Issues Arising from Delivering Mental Health Services in School Settings. Psychoanalytic Psychotherapy, 21, 1-19.

https://doi.org/10.1080/02668730601181077

National Association of School Psychologists (2010). Model for Comprehensive and Integrated School Psychological Services. NASP Document.

National Foundation for Educational Research (NFER) (2016). Developing School Counseling Services for Children and Young People in Wales.

https://www.nfer.ac.uk/search/?searchTerm=school+counselling

Nastasi, B., Moore, R. B., \& Varjas, K. M. (2004). School-Based Mental Health Services: Creating Comprehensive and Culturally Specific Programs. Washington DC: American Psychological Association. https://doi.org/10.1037/10724-000

Neece, C., Green, S., \& Baker, B. (2012). Parenting Stress and Child Behavior Problems: A Transactional Relationship across Time. American Journal on Intellectual and Developmental Disabilities, 117, 48-66. https://doi.org/10.1352/1944-7558-117.1.48

Paternite, C. E. (2005). School-Based Mental Health Programs and Services: Overview and Introduction to the Special Issue. Journal of Abnormal Child Psychology, 6, 657-663. https://doi.org/10.1007/s10802-005-7645-3

Putzu-Williams, S. (2015). Understanding Anger. In L. French, \& R. Klein (Eds.), Therapeutic Practice in Schools (Vol. 2, pp. 71-80). New York, NY: Routledge.

Reddy, L. A., \& Richardson, L. (2006). School-Based Prevention and Intervention Programs for Children with Emotional Disturbance. Education and Treatment of Children, 29, 1-26.

Renouf, A., Brendgen, M., Séguin, J. R., Vitaro, R., Boivin, M., \& Perusse, D. (2010). Interactive Links between Theory of Mind, Peer Victimization, and Reactive and Proactive Aggression. Journal of Abnormal Child Psychology, 38, 1109.

https://doi.org/10.1007/s10802-010-9432-z

Rhodes, J. (2007). Mentoring and Resilience: Building Resilience in Children, Families and Communities.

http://www.nuigalway.ie/sites/childandfamilyresearch/downloads/crfc_2007_jeanrhode s.pdf

Roeser, R., \& Eccles, J. (2014). Schooling and the Mental Health of Children and Adolescents in USA. In M. Lewis, \& K. Rudolph (Eds.), Handbook of Developmental Psychopathology (3rd ed., pp. 163-184). New York, NY: Springer.

https://doi.org/10.1007/978-1-4614-9608-3_9 
Rohner, R. P. (2016). Introduction to Interpersonal Acceptance-Rejection Theory (IPAR Theory) and Evidence. Online Readings in Psychology and Culture, 6, 4. https://doi.org/10.9707/2307-0919.1055

Roth, A., \& Fonagy, P. (2005). What Works for Whom? A Critical Review of Psychotherapeutic Research. New York, NY: The Guilford Press.

Sameroff, A. (2009). The Transactional Model. How Children and Contexts Shape Each Other. Washington DC: American Psychological Association.' https://doi.org/10.1037/11877-001

Sameroff, A. (2014). A Dialectic Integration of Development for the Study of Psychopathology. In M. Lewis, \& K. D. Rudolph (Ed.), Handbook of Developmental Psychopathology (pp. 25-44). New York, NY: Springer. https://doi.org/10.1007/978-1-4614-9608-3_2

Scriva, M. L., Heriot, S. A., \& Kourkoutas, E. (2015). Emotion Regulation and Interpersonal Schemata in Depressed and Aggressive Youth. In E. Kourkoutas, \& A. Hart (Eds.), Innovative Practices for Children and Adolescents with Psychosocial Difficulties and Disabilities (pp. 113-151). Newcastle: Cambridge Scholar Publications.

Serbin, L. A., \& Krap, J. (2004). The Intergenerational Transfer of Psychosocial Risk: Mediators of Vulnerability and Resilience. Annual Review of Psychology, 55, 333-363. https://doi.org/10.1146/annurev.psych.54.101601.145228

Sharry, J. (2004). Counselling Children, Adolescents and Families: A Strengths-Based Approach. London: Sage.

Smith, B., \& Fox, L. (2002). Systems of Service Delivery: A Synthesis of Evidence Relevant to Young Children at Risk for or Who Have Challenging Behavior. Center for Evidence-Based Practice: Young Children with Challenging Behavior. http://www.challengingbehavior.org

Snyder, J. (2016). Coercive Family Processes in the Development of Externalizing Behavior: Incorporating Neurobiology into Intervention Research. In T. Beauchaine, \& S. Hinshaw (Eds.), The Oxford Handbook of Externalizing Spectrum Disorders (pp. 267-285). New York, NY: Oxford University Press.

Sroufe, L. A., Duggal, S., Weinfield, N., \& Carlson, E. (2000). Relationships, Development, and Psychopathology. In A. J. Sameroff, M. Lewis, \& S. M. Miller (Eds.). Handbook of Developmental Psychopathology (2nd ed., pp. 75-91). New York, NY: Klewer Academic/Plenum Publishers. https://doi.org/10.1007/978-1-4615-4163-9_5

Sroufe, L. A., Egeland, B., Carlson, A. E. W., \& Collins, A. C. (2005). The Development of the Person: The Minnesota Story of Risk and Adaptation from Birth to Adulthood. New York, NY: Guilford Press.

Stavrou, P.-D. (2018a). Psychoanalytic Psychotherapy as a Method of Treatment for a Special Educator Experiencing Disengagement in Relation to Her Profession: A Case Study. Global Journal of Human Social Sciences, 18, 47-59.

Stavrou, P.-D. (2018b). Children's Self-Image Following Abuse, Development of Resilience and Family Context Impact: A Clinical Psychodynamic Approach. Advances in Social Sciences Research Journal, 5, 308-329.

Stavrou, P. D., \& Kourkoutas, E. (2017). School Based Programs for Socioemotional Development of Children with or without Difficulties: Promoting Resilience. American Journal of Educational Research, 5, 131-137.

Steiner, H., Silverman, M., Karnik, N. S., Huemer, J., Plattner, B., Clark, C. E., Blair, J. R., \& Haapanen, R. (2011). Psychopathology, Trauma and Delinquency: Subtypes of Aggression and Their Relevance for Understanding Young Offenders. Child and Adolescent Psychiatry and Mental Health, 5, 21. http://www.capmh.com/content/5/1/21 https://doi.org/10.1186/1753-2000-5-21 
Thornberry, T. P., Freman-Galant, A., Lizotte, A. J., Krohn, M. D., \& Smith, C. A. (2003). Linked Lives: The Intergenerational Transmission of Antisocial Behavior. Journal of Abnormal Child Psychology, 2, 171-184. https://doi.org/10.1023/A:1022574208366

Timimi, S. (2002). Pathological Child Psychiatry and the Medicalization of Childhood. Hove: Brunner-Routledge.

Timimi, S., \& Radcliffe, N. (2005). The Rise and Rise of ADHD. In C. Newnes, \& N. Radcliffe (Eds.), Making and Breaking Children's Lives (pp. 63-70). Ross-on-Wye: PCCCS Books.

Tremblay, R. E. (2003). Why Socialization Fails: The Case of Chronic Physical Aggression. In B. B. Lahey, T. E. Moffit, \& A. Caspi (Eds.), Causes of Conduct Disorders and Juvenile Delinquency (pp. 182-226). New York, NY: Guilford Press.

Tremblay, R. E. (2010), Developmental Origins of Disruptive Behavior Problems: The "Original Sin" Hypothesis, Epigenetics and Their Consequences for Prevention. Journal of Child Psychology and Psychiatry, 51, 341-367.

https://doi.org/10.1111/j.1469-7610.2010.02211.x

Walker, H., Ramsey, E., \& Gresham, F. (2004). Antisocial Behaviour in School. Evidence Based Practices (2nd ed.). Belmont, CA: Wadsworth.

Wampold, B., \& Imel, Z. (2015). The Great Psychotherapy Debate: The Evidence for What Makes Psychotherapy Work. New York, NY: Routledge.

Weare, K. (2000). Promoting Mental, Emotional and Social Health. A Whole School Approach. London: Routledge.

Weare, K. (2005). Taking a Positive, Holistic Approach to the Mental and Emotional Health and Well-Being of Children and Young People. In C. Newnes, \& N. Radcliffe (Eds.), Making and Breaking Children's Lives (pp. 115-122). Ross-on-Wye: PCCCS Books.

Weare, K., \& Gray, G. (2003). What Works in Promoting Children's Emotional and Social Competence and Well-Being? London: Department of Education and Skills.

Weist, M. D. (2003). Promoting Paradigmatic Change in Child and Adolescent Mental Health and Schools. School Psychology Review, 32, 336-341.

Weisz, J. R. (2004). Psychotherapy for Children and Adolescents: Evidence-Based Treatments and Case Examples. New York, NY: Cambridge University Press. https://doi.org/10.1017/CBO9780511734960

Williams, J. H., Ayers, C. D., Van Dorn, R. A., \& Arthur, M. W. (2004). Risk and Protective Factors in the Development of Delinquency and Conduct Disorder. In M. W. Fraser (Ed.), Risk and Resilience in Childhood. An Ecological Perspective (pp. 209-250). Washington DC: NAWS Press.

Winship, G., \& MacDonald, S. G. (2018). The Essentials of Counselling and Psychotherapy in Primary Schools. New York, NY: Routledge.

Wyman, P. A. (2003). Emerging Perspectives on Context Specificity of Children's Adaptation and Resilience: Evidence from a Decade of Research with Urban Children in Adversity. In S. S. Luthar (Ed.), Resilience and Vulnerability. Adaptation in the Context of Childhood Adversities (pp. 293-317). New York, NY: Cambridge University Press. https://doi.org/10.1017/CBO9780511615788.014

Young, K. R., Marchant, M., \& Wilder, L. K. (2004). School-Based Interventions for Students with Emotional and Behavioral Disorders. In P. Allen-Mears, \& M. W. Fraser (Eds.), Interventions with Children and Adolescents. An Interdisciplinary Perspective (pp. 175-204). Boston: Pearson. 
Zoccolillo, M., Romano, É., Joubert, D., Mazzarello, T., Côté, S., Boivin, M. et al. (2005). The Intergenerational Transmission of Aggression and Antisocial Behaviour. In R. E. Tremblay, W. W. Hartup, \& J. Archer (Eds.), Developmental Origins of Aggression (pp. 353-375). New York, NY: Guildford Press. 